JERZY BABIAK

Poznań

\title{
Zmiany w strukturze rolnictwa krajów Unii Europejskiej
}

Rozpatrując strukturę agrarną państw Unii Europejskiej, można zauważyć wyraźną tendencję zmian. Począwszy od Planu Mansholta z 1968 r. w kwestii obrotu gruntami rolnymi Unia wyznacza pewne kierunki ${ }^{1}$. Przede wszystkim położono nacisk na poprawę struktury agrarnej poprzez powiększanie obszaru gospodarstw, likwidację tych mało wydajnych, a także zmniejszenie nadwyżek produktów rolnych. Wstępne założenia Planu nie zostały jednak w pełni osiagnnięte. Niemniej od tamtego czasu w strukturze obszarowej poszczególnych krajów zaszły ogromne zmiany.

\section{Struktura agrarna w krajach Unii Europejskiej}

W powojennej Europie procesy koncentracji ziemi następowały w dwóch zasadniczych etapach. Pierwszy rozpoczął się tuż po drugiej wojnie światowej i trwał do lat 60., charakteryzując się powolną dynamiką i opierając się na procesach przebiegających samoczynnie. Zmiany w obszarze wykorzystywanej techniki produkcji w rolnictwie, pozytywnie wpływały na rozwój dużych gospodarstw rodzinnych, jak również jednostek mniejszych (do ok. 100 ha) ${ }^{2}$. Należy podkreślić, iż w przeobrażeniach tych poza mechanizmami konkurencji rynkowej i czynnikami ekonomicznymi w zasadzie nie uczestniczyły inne determinanty. Przeciętny roczny wskaźnik ubytku liczby gospodarstw oscylował wówczas w granicach 1-2\%. Dla przykładu warto przytoczyć chociażby dane dotyczące Francji, gdzie osiągnął 1,4\%, w Holandii sięgnął pułapu 1,8\%, w Danii zaś zaledwie $0,3 \%^{3}$.

1 W 1968 r. sformułowano pierwsze założenia wspólnej polityki przemian strukturalnych na całym obszarze EWG, znane jako tzw. Plan Manholta. Myślą przewodnią tych propozycji była teza, że polityka rolna winna stymulować, a jednocześnie ukierunkowywać przemiany w strukturze społeczno-ekonomicznej rolnictwa. Zaprojektowano w tym celu wiele środków o charakterze prawnym i ekonomicznym, których uruchomienie miało doprowadzić do utworzenia jednostek produkcyjnych o dostatecznej wielkości, łatwiej i skuteczniej reagujących na wskazania rynku. Równocześnie w związku z zakładanym radykalnym zmniejszeniem liczby gospodarstw, przewidziano wiele środków zachęcających ludność wiejską do rezygnacji z pracy w rolnictwie. Dotyczyły one generalnie świadczeń finansowych dla osób, które zaniechają prowadzenia gospodarstwa oraz udzielenia pomocy przy zorganizowaniu warunków życia tym, którzy zaprzestaną pracy w rolnictwie. Patrz szerzej: M. Ciepielowska, Wspólna polityka rolna EWG, PWN, Warszawa 1981.

2 Por. M. Mieszczankowski, O tendencjach koncentracji $w$ rolnictwie, „Życie gospodarcze” 1976, nr 47.

3 Por. J. Wierzbicki, Problem koncentracji ziemi i gospodarstw w wybranych krajach europejskich, w: Problemy rolnictwa światowego, t. I, SGGW - AR, Warszawa 1978, s. 125. 
Drugi etap przeobrażeń strukturalnych rozpoczął się wraz z początkiem lat 60 . $\mathrm{i}$ trwa nadal. Charakterystycznym dla tego okresu jest wysokie tempo zmian w strukturze agrarnej, stymulowane przez politykę realizowaną na poziomie poszczególnych rządów, jak i całej Wspólnoty.

Tabela 1

Gospodarstwa rolne w wybranych krajach europejskich w latach 1966/67-1975

\begin{tabular}{|c|c|c|c|c|c|c|}
\hline \multirow{3}{*}{ Kraj } & \multicolumn{6}{|c|}{ Lata } \\
\hline & $1966 / 67$ & $1970 / 71$ & 1975 & $1970 / 71-1966 / 67$ & 1975-1970/71 & 1975-1966/67 \\
\hline & \multicolumn{3}{|c|}{ tys. } & \multicolumn{3}{|c|}{$\%$} \\
\hline Belgia & 214,8 & 184,0 & 138,1 & 85,7 & 75,1 & 64,3 \\
\hline Dania & - & - & 132,3 & - & - & - \\
\hline Francja & 1708,0 & 1587,6 & 1315,1 & 93,0 & 82,8 & 77,0 \\
\hline Holandia & 247,0 & 184,6 & 162,6 & 74,7 & 88,1 & 65,8 \\
\hline Irlandia & - & - & 228,0 & - & - & - \\
\hline Luksemburg & 8,6 & 7,6 & 6,2 & 88,4 & 81,6 & 72,1 \\
\hline Niemcy & 1246,0 & 1074,6 & 907,9 & 86,2 & 84,5 & 72,9 \\
\hline Wielka Brytania & - & - & 280,6 & - & - & - \\
\hline Włochy & 2980,5 & 2849,9 & 2664,2 & 95,6 & 93,5 & 89,4 \\
\hline
\end{tabular}

- brak danych.

Źródło: Farm structure. Historical results - Surveys from 1966/67 to 1997. Final version: October 2000, EUROSTAT, European Communities, Luxemburg 2000, s. 23.

Z tabeli 1 wynika, że w latach 1966/67-1975 najwięcej gospodarstw przestało istnieć w Belgii i Holandii. Oba państwa odnotowały ponad 34\% spadek ich liczby w ciągu niespełna dekady, przy czym w Holandii ponad 1/4 gospodarstw zniknęła w latach 1966/67-1970/71 natomiast w Belgii podobna ilość ubyła w następnym 5-leciu. Najmniejszą różnicę można zauważyć we Włoszech, gdzie pomimo powyżej $10 \%$ spadku, nadal w połowie lat 70 . pozostawało ponad 2,5 mln jednostek. Niemniej należy w tym miejscu podkreślić, że spadkowe tendencje w liczbie gospodarstw nastapiły we wszystkich rozpatrywanych państwach i to zarówno tych o korzystnej strukturze gospodarstw, jak i tych charakteryzujących się rozdrobnieniem agrarnym (np. wspominane Włochy).

Następne trzy dekady przyniosły jeszcze poważniejsze zmiany w liczbie gospodarstw krajów europejskich, przyczyniając się tym samym do koncentracji gruntów rolnych.

Tabela 2

Liczba gospodarstw w krajach Unii Europejskiej w latach 1975-2007

\begin{tabular}{|c|c|c|c|c|c|c|c|c|}
\hline \multirow{3}{*}{ Kraj } & \multicolumn{8}{|c|}{ Lata } \\
\hline & 1975 & $1979 / 80$ & 1985 & $1989 / 90$ & 1995 & 2000 & 2003 & 2007 \\
\hline & \multicolumn{8}{|c|}{ tys. } \\
\hline 1 & 2 & 3 & 4 & 5 & 6 & 7 & 8 & 9 \\
\hline Austria & - & - & - & - & 221,8 & 199,5 & 173,8 & 165,4 \\
\hline
\end{tabular}




\begin{tabular}{|l|c|c|c|c|c|c|r|r||}
\hline \multicolumn{1}{|c|}{1} & 2 & 3 & 4 & 5 & 6 & 7 & 8 & 9 \\
\hline Belgia & 138,1 & 115,1 & 97,8 & 85,0 & 71,0 & 61,7 & 54,9 & 48,0 \\
\hline Dania & 132,3 & 122,7 & 92,4 & 81,3 & 68,8 & 57,8 & 48,6 & 44,6 \\
\hline Finlandia & - & - & - & - & 101,0 & 81,2 & 75,0 & 68,2 \\
\hline Francja & 1315,1 & 1255,3 & 1056,9 & 923,6 & 734,8 & 664,0 & 614,0 & 527,4 \\
\hline Grecja & - & - & 951,6 & 850,1 & 802,4 & 817,1 & 824,5 & 860,2 \\
\hline Hiszpania & - & - & - & 1593,6 & 1277,6 & 1287,4 & 1140,7 & 1043,9 \\
\hline Holandia & 162,6 & 148,7 & 135,9 & 124,8 & 113,2 & 101,6 & 85,5 & 76,7 \\
\hline Irlandia & 228,0 & 223,5 & 220,2 & 170,6 & 153,4 & 141,5 & 135,6 & 128,2 \\
\hline Luksemburg & 6,2 & 5,2 & 4,4 & 4,0 & 3,2 & 2,8 & 2,5 & 2,3 \\
\hline Niemcy & 907,9 & 849,9 & 740,5 & 653,6 & 566,9 & 472,0 & 412,3 & 370,5 \\
\hline Portugalia & - & - & - & 598,7 & 450,6 & 416,0 & 359,3 & 275,1 \\
\hline Szwecja & - & - & - & - & 88,8 & 81,4 & 68,0 & 72,6 \\
\hline Wielka Brytania & 280,6 & 268,6 & 258,5 & 243,1 & 234,5 & 233,3 & 280,6 & 299,8 \\
\hline Włochy & 2664,2 & 2832,4 & 2801,1 & 2664,6 & 2482,1 & 2153,7 & 1963,8 & 1679,4 \\
\hline
\end{tabular}

- brak danych;

a dotyczy 1999/2000 Farm structure - 1999/2000 survey, EUROSTAT, European Communities, Luxemburg 2003, tab. 1, s. 67.

Źródło: Farm structure. Historical results - Surveys from 1966/67 to 1997. Final version: October 2000, EUROSTAT, European Communities, Luxemburg 2000, s. 23, EUROSTAT, Number of agricultural holdings[tag00001], data sporządzenia: 1.07.2010.

W latach 1975-2007 wszystkie kraje europejskie zamieszczone w tabeli 2 zanotowały znaczny spadek jednostek produkcyjnych w rolnictwie. Najwięcej, bo o ok. 60\% gospodarstw ubyło w Danii (66,3\%), Belgii (65,2\%), Luksemburgu (62,9\%), Francji $(59,9 \%)$ i Niemczech (59,2\%). Warto podkreślić, że są to jednocześnie kraje, z którymi Polska z uwagi na zbliżony profil produkcji rolnictwa musi konkurować na wspólnotowym rynku. Wyjątek w skali Europy stanowi Wielka Brytania, w której po niespełna 17\% spadku liczby jednostek produkcyjnych w latach 1975-2000, nastąpił ich przyrost aż o $28,5 \%$ w porównaniu do najniższej liczby, tj. z roku 2000. Ostatecznie w skali całego okresu trzech dekad, kraj ten zanotował 6,8\% wzrost ich liczby, przy czym warto w tym miejscu zasygnalizować, że znaczna część tej zwyżki mieści się w obszarze do 5 ha. Ciekawie w świetle powyższych wyników prezentują się także Włochy, ze swoją niezwykle rozdrobnioną strukturą agrarną. Mimo, że w ciagu omawianych trzech dekad zlikwidowano w tym kraju niemalże 1 mln gospodarstw, co dało najniższy wśród porównywanych państw spadek (o 37\%), to jednak nadal pozostaje ich ponad 1,6 mln. Na uwagę bez wątpienia zasługuje także Portugalia, w której liczba jednostek produkcyjnych odnotowała ponad 54\% spadek w czasie niemalże dwa razy krótszym niż inne państwa osiagające podobne wyniki.

Wyniki zawarte w tabeli 3 są kolejnym potwierdzeniem tezy o zniżkowych tendencjach liczby gospodarstw państw europejskich. Poza nielicznymi wyjątkami wszystkie prezentowane państwa zanotowały wyraźny ich ubytek. Największą dynamikę spadku ilości jednostek produkcyjnych odnotowano w pierwszej połowie lat 80 . w Danii, kiedy ich liczba zmniejszała się średnio o 4,9\% w skali roku. Podobny poziom - średnio 4,8\% spadku każdego roku, osiagnęła Portugalia w latach 2000-2007. Chwilowy wzrost ich liczby można było zaobserwować w Hiszpanii u schyłku lat 90. ubiegłego wieku i obecnie w Grecji, przy czym warto zauważyć, że w tym okresie wzrostowi 
uległa liczba gospodarstw większych (powyżej 20 ha) kosztem jednostek niewielkich - do 5 ha w przypadku Hiszpanii i tych z przedziału 5-20 ha w Grecji. Niewielką zwyżkę ilości jednostek zanotowano także we Włoszech pod koniec lat 70., później jednak liczba ta systematycznie spadała. Jedynie w Wielkiej Brytanii, po ok. 5\% średniorocznym spadku w latach 1975-1995, od 2000 r. ich liczba rośnie.

Tabela 3

Zmiany liczby gospodarstw w krajach Unii w latach 1975-2007

\begin{tabular}{|c|c|c|c|c|c|c|c|}
\hline \multirow{3}{*}{ Kraj } & \multicolumn{7}{|c|}{ Lata } \\
\hline & 1979/80-1975 & $1985-1979 / 80$ & $1989 / 90-1985$ & $1995-1989 / 90$ & $2000-1995$ & $2007-2000$ & $2007-1975$ \\
\hline & \multicolumn{7}{|c|}{$\%$} \\
\hline Austria & - & - & - & - & 89,9 & 82,9 & $74,6 \mathrm{c}$ \\
\hline Belgia & 83,3 & 85,0 & 86,9 & 83,5 & 86,9 & 77,8 & 34,8 \\
\hline Dania & 92,7 & 75,3 & 88,0 & 84,6 & 84,0 & 77,2 & 33,7 \\
\hline Finlandia & - & - & - & - & 80,4 & 84,0 & $67,5^{\mathrm{c}}$ \\
\hline Francja & 95,5 & 84,2 & 87,4 & 79,6 & 90,4 & 79,4 & 40,1 \\
\hline Grecja & - & - & 89,3 & 94,4 & 101,8 & 105,3 & $90,4^{\mathrm{a}}$ \\
\hline Hiszpania & - & - & - & 80,2 & 100,8 & 81,1 & $65,5^{\mathrm{b}}$ \\
\hline Holandia & 91,5 & 91,4 & 91,8 & 90,7 & 89,8 & 75,5 & 47,2 \\
\hline Irlandia & 98,0 & 98,5 & 77,5 & 89,9 & 92,2 & 90,6 & 56,2 \\
\hline Luksemburg & 93,9 & 84,6 & 90,9 & 80,0 & 87,5 & 82,1 & 37,1 \\
\hline Niemcy & 93,6 & 87,1 & 88,3 & 86,7 & 83,3 & 78,5 & 40,8 \\
\hline Portugalia & - & - & - & 75,3 & 92,3 & 66,1 & $45,9^{b}$ \\
\hline Szwecja & - & - & - & - & 91,7 & 89,2 & $81,8^{\mathrm{c}}$ \\
\hline Wielka Brytania & 95,7 & 96,2 & 94,0 & 96,5 & 99,5 & 128,5 & 106,8 \\
\hline Włochy & 106,3 & 98,9 & 95,1 & 93,2 & 86,8 & 78,0 & 63,0 \\
\hline
\end{tabular}

- brak danych;

a dotyczy zmiany w latach 1985-2007;

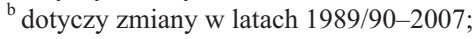

${ }^{\mathrm{c}}$ dotyczy zmiany w latach 1995-2007.

Źródło: Obliczenia własne na podstawie jak w tabeli 2.

Unia Europejska jest zróżnicowana pod względem struktury agrarnej. Wynika to w głównej mierze $\mathrm{z}$ uwarunkowań przyrodniczych oraz poziomu zaawansowania przekształceń strukturalnych. Można jednakże zauważyć ogólne tendencje tych przemian w kierunku zmniejszenia liczby gospodarstw rolnych, a także stymulacji wzrostu powierzchni jednostek produkcyjnych. Te korzystne z punktu widzenia możliwości konkurowania na wspólnotowym rynku zmiany są procesami powolnymi i wymagają uruchomienia mechanizmów stymulacyjnych tak na poziomie unijnym, jak i krajowym. Stąd też rządy wielu państw wprowadzają ustawową lub nawet konstytucyjną ochronę gospodarstw rodzinnych ${ }^{4}$,

${ }^{4}$ W kwestiach zagwarantowanego konstytucyjnie wsparcia poprawy ustroju rolnego można w ustawodawstwach poszczególnych krajów UE znaleźć szeroki wachlarz zastosowanych środków. Poczynając od szczegółowych regulacji dotyczących struktury rolnictwa poprzez te pośrednio jej dotyczące, kończąc na konstytucjach, które pomijają problem określenia podstaw ustroju rolnego. Państwowa ingerencja w celu ochrony gospodarstw rodzinnych sprowadza się natomiast do wprowadzania ograniczeń w swobodzie obrotu nieruchomościami rolnymi w celu zapobiegania nieracjonalnym ich podziałom, stosowania 
które stanowią podstawę ustroju rolnego ${ }^{5}$. W celu przyspieszania pożądanych zmian kraje zachodnioeuropejskie stosują ponadto instytucjonalne narzędzia kontroli i regulacji obrotu gruntami rolnymi ${ }^{6}$.

Ogólne tendencje zmian struktury obszarowej odzwierciedlające poziom skuteczności stosowanych mechanizmów wspierania przeobrażeń agrarnych w krajach Wspólnoty można zauważyć także na poziomie poszczególnych grup obszarowych.

Tabela 4

Struktura gospodarstw w wybranych krajach Unii Europejskiej w latach 1979/80-2007

\begin{tabular}{|c|c|c|c|c|c|c|c|c|c|c|c|}
\hline & & \multicolumn{10}{|c|}{ Grupy obszarowe } \\
\hline \multirow{2}{*}{\multicolumn{2}{|c|}{ Kraj }} & \multicolumn{2}{|c|}{ do 5 ha } & \multicolumn{2}{|c|}{$5-20$ ha } & \multicolumn{2}{|c|}{$20-50$ ha } & \multicolumn{2}{|c|}{ 50-100 ha } & \multicolumn{2}{|c|}{100 ha i więcej } \\
\hline & & tys. & $\%$ & tys. & $\%$ & tys. & $\%$ & tys. & $\%$ & tys. & $\%$ \\
\hline 1 & 2 & 3 & 4 & 5 & 6 & 7 & 8 & 9 & 10 & 11 & 12 \\
\hline \multirow[t]{4}{*}{ Austria } & A & - & - & - & - & - & - & - & - & - & - \\
\hline & B & - & - & - & - & - & - & - & - & - & - \\
\hline & $\mathrm{C}$ & 72,6 & 36,4 & 82,9 & 41,6 & 35,1 & 17,6 & 6,0 & 3,0 & 2,9 & 1,5 \\
\hline & $\mathrm{D}$ & 55,3 & 33,4 & 65,5 & 39,6 & 33,3 & 20,1 & $11,3^{\mathrm{a}}$ & 6,8 & - & - \\
\hline
\end{tabular}

zasad niepodzielności gospodarstw rodzinnych w postępowaniu spadkowym, zakazu podziału gospodarstw utworzonych w wyniku kompleksowych prac urządzeniowo-rolnych dokonanych na koszt państwa, czy też szeregu innych, dodatkowych mechanizmów ochronnych. Patrz szerzej: A. Kołodziej, Unia Europejska. Ewolucja polityki strukturalnej, „Agroprzemiany” 2002, nr 3.

5 W tym miejscu należy jednak zaznaczyć, iż na poziomie Unii Europejskiej pojęcie gospodarstwa rodzinnego nie zostało zdefiniowane, funkcjonuje natomiast termin: gospodarstwo rozwojowe, którego kryteria zbliżone są do krajowych definicji tego pierwszego. Pojęcie to zostało wprowadzone dyrektywą Rady z 17 kwietnia 1972 r. w sprawie modernizacji farm (dyrektywa Rady nr L 159 z 17 kwietnia 1972 r. tzw. dyrektywa „modernizacyjna”, Dz. U. W. E. L 96 z 23 kwietnia 1972 r.).

6 We Francji jednostkami powołanymi do stymulowania rozwoju, powiększania i ochrony gospodarstw rodzinnych są Spółki Urządzeń i Osadnictwa Rolnego (SAFER). Do ich zadań należy także utrzymywanie równowagi popytu i podaży w obrocie ziemią rolniczą, komasacja gruntów, decyzje w zakresie wykorzystania ziemi w celach pozarolniczych, zarządzanie gruntami leśnymi, ochrona środowiska naturalnego oraz pomoc w tworzeniu nowych jednostek produkcyjnych. Spółki mają prawo ingerowania m.in. w transakcje, w wyniku których gospodarstwo utraciłoby rodzinny charakter. Wykorzystywać w tym celu mogą instytucję pierwokupu. W Niemczech natomiast kształtowaniem struktury obszarowej zajmują się organizacje niemieckich kółek osadniczych - Landgesselschaften, które mają prawo odkupić ziemie, w stosunku do których organ administracyjny nie wyraził zgody na transakcję sprzedaży. Taka sytuacja może nastąpić, gdy sprzedaż doprowadziłaby do nadmiernej koncentracji gruntów, nabywca nie posiada odpowiednich kwalifikacji rolniczych, ziemia nabywana jest w celach spekulacyjnych (nabywca nie ma zamiaru trwale włączyć zakupionego gruntu do swojego gospodarstwa i użytkować go w celach rolniczych) lub też gdy gospodarstwo w wyniku takiej transakcji utraciłoby samowystarczalność. Specyficznym ograniczeniem prawa niemieckiego jest także brak możliwości podziału gospodarstwa w sytuacji dziedziczenia. W Danii zaś jednostką zajmującą się kształtowaniem struktury gospodarstw jest Departament Struktur, który jest uprawniony do zakupu gruntów w celu poprawy lokalizacji gospodarstw, powiększenia ich obszaru, zachowania walorów krajobrazu wiejskiego, gromadzenia rezerwy ziemi na odszkodowania za utracone tereny rolnicze oraz na urządzanie terenów zieleni. Realizacji powyższych celów ma służyć m.in. prawo pierwokupu. Patrz szerzej: D. Stankiewicz, Ograniczenia w obrocie gruntami rolnymi w wybranych krajach Unii Europejskiej $w$ aspekcie prac nad stosownymi zmianami $w$ ustawodawstwie polskim, Kancelaria Sejmu, Biuro Studiów i Ekspertyz, Informacja nr 886, luty 2002 r.; A. Zadura, Kształtowanie struktury gospodarstwa w wybranych krajach UE, ,Biuletyn Informacyjny Ministerstwa Rolnictwa i Rozwoju Wsi oraz Agencji Restrukturyzacji i Modernizacji Rolnictwa” 2008, nr 1-2 (118). 


\begin{tabular}{|c|c|c|c|c|c|c|c|c|c|c|c|}
\hline 1 & 2 & 3 & 4 & 5 & 6 & 7 & 8 & 9 & 10 & 11 & 12 \\
\hline \multirow[t]{4}{*}{ Belgia } & A & 48,7 & 42,3 & 43,6 & 37,8 & 19,1 & 16,6 & 3,2 & 2,8 & 0,6 & 0,5 \\
\hline & $\mathrm{B}$ & 32,1 & 37,8 & 29,4 & 34,6 & 18,6 & 21,9 & 4,1 & 4,8 & 0,8 & 0,9 \\
\hline & C & 19,0 & 30,8 & 18,5 & 30,0 & 16,7 & 20,1 & 6,2 & 10,0 & 1,3 & 2,1 \\
\hline & $\mathrm{D}$ & 12,2 & 25,4 & 13,7 & 28,5 & 13,3 & 27,7 & $8,8^{\mathrm{a}}$ & 18,3 & - & - \\
\hline \multirow[t]{4}{*}{ Dania } & A & 16,7 & 13,6 & 53,7 & 43,7 & 40,9 & 33,3 & 9,4 & 7,7 & 2,1 & 1,7 \\
\hline & B & 2,2 & 2,7 & 32,2 & 39,6 & 31,3 & 38,5 & 12,2 & 15,0 & 3,4 & 3,7 \\
\hline & $\mathrm{C}$ & 2,0 & 3,5 & 21,0 & 36,3 & 17,2 & 29,7 & 11,5 & 19,9 & 6,2 & 10,7 \\
\hline & D & 1,7 & 3,8 & 17,2 & 38,5 & 10,5 & 23,5 & $15,3^{\mathrm{a}}$ & 34,2 & - & - \\
\hline \multirow[t]{4}{*}{ Finlandia } & A & - & - & - & - & - & - & - & - & - & - \\
\hline & B & - & - & - & - & - & - & - & - & - & - \\
\hline & $\mathrm{C}$ & 8,5 & 10,5 & 31,3 & 38,5 & 30,4 & 37,4 & 9,3 & 11,5 & 1,7 & 2,1 \\
\hline & D & 6,6 & 9,7 & 23,3 & 34,2 & 24,2 & 35,5 & $14,1^{\mathrm{a}}$ & 20,7 & - & - \\
\hline \multirow[t]{4}{*}{ Francja } & A & 352,6 & 28,1 & 406,9 & 32,4 & 348,0 & 27,7 & 114,3 & 9,1 & 33,6 & 2,7 \\
\hline & B & 248,8 & 26,9 & 235,5 & 25,5 & 259,7 & 28,1 & 131,2 & 14,2 & 48,3 & 5,2 \\
\hline & $\mathrm{C}$ & 193,4 & 29,1 & 131,8 & 19,9 & 137,8 & 20,8 & 122,1 & 18,4 & 78,8 & 11,9 \\
\hline & D & 130,4 & 24,7 & 100,6 & 19,1 & 99,2 & 18,8 & $197,1^{\mathrm{a}}$ & 37,4 & - & - \\
\hline \multirow[t]{4}{*}{ Grecja } & A & 788,3 & 78,9 & 196,5 & 19,7 & 12,4 & 1,2 & 1,4 & 0,1 & 0,3 & 0,03 \\
\hline & B & 645,2 & 75,9 & 183,1 & 21,5 & 18,0 & 2,0 & 2,9 & 0,3 & 1,0 & 0,1 \\
\hline & $\mathrm{C}$ & 624,4 & 76,7 & 161,4 & 19,8 & 23,9 & 2,9 & 3,3 & 0,4 & 0,9 & 0,1 \\
\hline & D & 655,1 & 76,2 & 167,7 & 19,5 & 30,3 & 3,5 & $7,1^{\mathrm{a}}$ & 0,8 & - & - \\
\hline \multirow[t]{4}{*}{ Hiszpania } & A & - & - & - & - & - & - & - & - & - & - \\
\hline & B & 971,4 & 61,0 & 410,4 & 25,8 & 124,9 & 7,8 & 48,8 & 3,1 & 38,2 & 2,4 \\
\hline & $\mathrm{C}$ & 740,5 & 57,5 & 332,9 & 25,9 & 114,2 & 8,9 & 51,4 & 4,0 & 48,5 & 3,8 \\
\hline & D & 551,4 & 52,8 & 279,7 & 26,8 & 111,7 & 10,7 & $101,2^{\mathrm{a}}$ & 9,7 & - & - \\
\hline \multirow[t]{4}{*}{ Holandia } & A & 48,6 & 32,7 & 65,6 & 44,1 & 30,7 & 20,6 & 3,4 & 2,3 & 0,4 & 0,3 \\
\hline & B & 40,3 & 32,3 & 46,9 & 37,6 & 31,6 & 25,3 & 5,3 & 4,2 & 0,7 & 0,6 \\
\hline & $\mathrm{C}$ & 31,7 & 31,2 & 33,3 & 32,8 & 28,2 & 27,8 & 7,2 & 7,1 & 1,2 & 1,2 \\
\hline & $\mathrm{D}$ & 21,5 & 28,0 & 23,1 & 30,1 & 21,0 & 27,3 & $11,2^{\mathrm{a}}$ & 14,6 & - & - \\
\hline \multirow[t]{4}{*}{ Irlandia } & A & 34,0 & 15,2 & 103,1 & 46,2 & 66,6 & 29,8 & 16,0 & 7,2 & 3,7 & 1,7 \\
\hline & B & 19,2 & 11,3 & 72,4 & 42,4 & 59,4 & 34,8 & 15,7 & 9,2 & 3,9 & 2,3 \\
\hline & $\mathrm{C}$ & 11,7 & 8,3 & 51,0 & 36,0 & 54,7 & 38,7 & 19,5 & 13,8 & 4,6 & 3,3 \\
\hline & D & 8,4 & 6,6 & 46,7 & 36,4 & 50,4 & 39,3 & $22,7^{\mathrm{a}}$ & 17,7 & - & - \\
\hline \multirow[t]{4}{*}{ Luksemburg } & A & 1,4 & 27,5 & 1,2 & 23,5 & 1,8 & 35,3 & 0,7 & 13,7 & 0,0 & 0,0 \\
\hline & B & 1,0 & 25,0 & 0,8 & 20,0 & 1,1 & 27,5 & 1,0 & 25,0 & 0,1 & 2,5 \\
\hline & $\mathrm{C}$ & 0,6 & 21,4 & 0,5 & 17,9 & 0,5 & 17,9 & 0,9 & 32,1 & 0,3 & 10,7 \\
\hline & $\mathrm{D}$ & 0,4 & 17,4 & 0,4 & 17,4 & 0,4 & 17,4 & $1,1^{\mathrm{a}}$ & 47,8 & - & - \\
\hline \multirow[t]{4}{*}{ Niemcy } & A & 301,8 & 35,5 & 339,4 & 39,9 & 178,4 & 21,0 & 260,0 & 3,1 & 4,3 & 0,5 \\
\hline & B & 218,6 & 33,4 & 225,6 & 34,5 & 153,1 & 23,4 & 44,4 & 6,8 & 11,9 & 1,8 \\
\hline & $\mathrm{C}$ & 117,6 & 24,9 & 161,3 & 34,2 & 114,4 & 24,2 & 54,3 & 11,5 & 24,4 & 5,2 \\
\hline & D & 83,6 & 22,6 & 119,6 & 32,3 & 81,9 & 22,1 & $85,4^{\mathrm{a}}$ & 23,0 & - & - \\
\hline \multirow[t]{4}{*}{ Portugalia } & $\mathrm{A}$ & 690,8 & 90,1 & 61,7 & 8,0 & 8,5 & 1,1 & 2,6 & 0,3 & 3,4 & 0,4 \\
\hline & B & 492,4 & 82,2 & 83,5 & 13,9 & 13,6 & 2,3 & 3,9 & 0,7 & 5,4 & 0,9 \\
\hline & $\mathrm{C}$ & 327,8 & 78,8 & 65,2 & 15,7 & 13,1 & 3,1 & 4,1 & 1,0 & 5,8 & 1,4 \\
\hline & D & 199,6 & 72,6 & 53,5 & 19,5 & 12,2 & 4,4 & $9,8^{\mathrm{a}}$ & 3,6 & - & - \\
\hline
\end{tabular}




\begin{tabular}{|c|c|c|c|c|c|c|c|c|c|c|c|}
\hline 1 & 2 & 3 & 4 & 5 & 6 & 7 & 8 & 9 & 10 & 11 & 12 \\
\hline \multirow[t]{4}{*}{ Szwecja } & A & - & - & - & - & - & - & - & - & - & - \\
\hline & B & - & - & - & - & - & & - & - & - & - \\
\hline & C & 9,8 & 12,0 & 31,0 & 38,1 & 21,7 & 26,7 & 12,5 & 15,4 & 6,4 & 7,9 \\
\hline & $\mathrm{D}$ & 10,9 & 15,0 & 27,3 & 37,6 & 16,5 & 22,7 & $17,9^{\mathrm{a}}$ & 24,7 & - & - \\
\hline \multirow{4}{*}{$\begin{array}{l}\text { Wielka } \\
\text { Brytania }\end{array}$} & A & 46,6 & 17,3 & 72,6 & 27,0 & 68,0 & 25,3 & 43,6 & 16,2 & 37,8 & 14,1 \\
\hline & B & 33,5 & 13,8 & 67,9 & 27,9 & 60,7 & 25,0 & 42,5 & 17,5 & 38,5 & 15,8 \\
\hline & C & 53,9 & 23,1 & 56,1 & 24,0 & 47,8 & 20,5 & 36,6 & 15,7 & 38,9 & 16,7 \\
\hline & D & 119,3 & 39,8 & 60,1 & 20,0 & 46,5 & 15,5 & $74,0^{\mathrm{a}}$ & 24,7 & - & \\
\hline \multirow[t]{4}{*}{ Włochy } & A & 2218,5 & 78,3 & 489,0 & 17,3 & 86,9 & 3,1 & 23,3 & 0,8 & 14,7 & 0,5 \\
\hline & B & 2099,1 & 78,8 & 439,5 & 16,5 & 87,7 & 3,3 & 24,7 & 0,9 & 13,7 & 0,5 \\
\hline & C & 1686,1 & 78,3 & 346,8 & 16,1 & 82,8 & 3,8 & 23,9 & 1,1 & 12,6 & 0,6 \\
\hline & D & 1230,7 & 73,3 & 325,3 & 19,4 & 83,4 & 5,0 & $40,2^{\mathrm{a}}$ & 2,4 & - & - \\
\hline
\end{tabular}

- brak danych;

A - dotyczy 1979/80;

B - dotyczy 1989/90;

C - dotyczy 1999/2000;

D - dotyczy 2007;

${ }^{\text {a }}$ dotyczy przedziału 50 ha i więcej.

Źródło: Obliczenia własne na podstawie Agriculture. Statistical yearbook. Data 1992-2001, EUROSTAT, European Communities, Luxemburg 2002, Tab. 4.3, s. 105-106, EUROSTAT, Agricultural holdings with agricultural area $<5$ ha - [tag00002], data sporządzenia: 1.07.2010, EUROSTAT, Agricultural holdings with agricultural area $5-<20 \mathrm{ha}-$ [tag00003], data sporządzenia: 1.07.2010, EUROSTAT, Agricultural holdings with agricultural area $20-<50$ ha $-[\operatorname{tag} 00004]$, data sporządzenia: 1.07.2010, EUROSTAT, Agricultural holdings with agricultural area $>=50 \mathrm{ha}-[\operatorname{tag} 00005]$, data sporządzenia: 1.07.2010.

Analizując zaprezentowane $\mathrm{w}$ tabeli 4 dane można zauważyć ogólne tendencje spadkowe co do liczby gospodarstw do 5 ha oraz z przedziału 5-20 ha. Liczba jednostek produkcyjnych $\mathrm{z}$ grupy obszarowej $20-50$ ha ulegała w poszczególnych państwach okresowym wahaniom. Jednocześnie w większości krajów wzrastała liczba gospodarstw największych o obszarze powyżej 50 ha. W dwóch państwach ten przyrost był szczególnie wyraźny; i tak we Francji w latach 1979/80-2007 wzrost w tej grupie obszarowej sięgnął $25,6 \%$, w Luksemburgu zaś aż 34,1\%. Zgoła odmiennymi tendencjami, co zostało już wcześniej wspomniane, charakteryzuje się Wielka Brytania. Najmniejsze gospodarstwa - do 5 ha - zanotowały w ciagu tych niespełna trzech dekad aż 22,5\% wzrost ich liczby, przy czym najwyższy, bo 16,7\% nastąpił w ostatnim siedmioleciu. Zmiany te dokonały się kosztem spadku ilości jednostek produkcyjnych z pozostałych grup obszarowych.

Niezwykle cennych informacji o przeobrażeniach agrarnych, jakie zaszły w rolnictwie krajów Unii Europejskiej w okresie niespełna dwudziestu lat, dostarczają dane na temat średniej wielkości gospodarstw. Warto jednak zaznaczyć, że dotyczą one powierzchni ogólnej gospodarstwa, do których zaliczono użytki rolne, trwałe pastwiska, trwałe uprawy oraz ogródki przydomowe, stąd też dane te różnić się mogą od statystyk krajowych.

Z tabeli 5 wynika, że w przytoczonym okresie średni obszar gospodarstwa przyjmuje wyraźnie tendencję wzrostową. Spośród rozważanych tutaj krajów Unii najwyższą średnią mają gospodarstwa w Wielkiej Brytanii, jednakże warto zauważyć, że w ciągu 
rozpatrywanych 17 lat, kategoria ta odnotowała najmniejszy wzrost (w porównaniu z pozostałymi państwami), bo zaledwie ok. $15 \%$. Z uwagi na profil polskiej produkcji rolnej szczególnie warto zwrócić uwagę na takie kraje jak: Niemcy, w których średni obszar wzrósł o 46,1\%, Francja - wzrost o 45,2\%, Dania (43\%), Hiszpania $(39,4 \%)$. Pomijając Portugalię (wzrost o 63,4\%), Belgię (o 46,8\%) i Luksemburg (o 45,2\%), są to jednocześnie państwa z najwyższym przyrostem średniego obszaru gospodarstwa. Warto w tym miejscu jednak podkreślić, że mimo iż Portugalia zanotowała najwyższy skok, to jednak średni obszar gospodarstwa w tym kraju nie odbiega tak znacząco od poziomu istniejącego w Polsce. Ciekawie prezentują się także wyniki dwóch krajów skandynawskich, tj. Finlandii i Szwecji, w których średnia wzrosła o ok. 35\% w ciagu zaledwie 12 lat.

Tabela 5

Średni obszar gospodarstwa w krajach Unii Europejskiej

\begin{tabular}{||l|c|c|c|c||}
\hline \multirow{3}{*}{ Kraj } & \multicolumn{3}{|c||}{ Lata } \\
\cline { 2 - 5 } & $\mathbf{1 9 8 9 / 1 9 9 0}$ & $\mathbf{1 9 9 5}$ & $\mathbf{1 9 9 9 / 2 0 0 0}$ & $\mathbf{2 0 0 7}$ \\
\cline { 2 - 5 } & \multicolumn{3}{|c||}{ ha } \\
\hline Austria & - & 15,4 & 17,0 & 19,7 \\
\hline Belgia & 15,8 & 19,1 & 22,6 & 29,7 \\
\hline Dania & 34,2 & 39,6 & 45,7 & 34,0 \\
\hline Finlandia & - & 21,7 & 27,3 & 55,7 \\
\hline Francja & 30,5 & 38,5 & 42,0 & 5,6 \\
\hline Grecja & 4,3 & 4,5 & 4,4 & 25,4 \\
\hline Hiszpania & 15,4 & 19,7 & 20,3 & 24,9 \\
\hline Holandia & 16,1 & 17,7 & 20,0 & 34,1 \\
\hline Irlandia & 26,0 & 28,2 & 31,4 & 58,4 \\
\hline Luksemburg & 32,0 & 39,9 & 45,4 & 48,4 \\
\hline Niemcy & 26,1 & 30,3 & 36,3 & 18,3 \\
\hline Portugalia & 6,7 & 8,7 & 9,3 & 51,9 \\
\hline Szwecja & - & 34,4 & 37,7 & 80,3 \\
\hline Wielka Brytania & 67,9 & 70,1 & 67,7 & 9,0 \\
\hline Włochy & 5,6 & 5,9 & 6,1 & \\
\hline \hline
\end{tabular}

- brak danych.

Źródło: Farm structure - 1999/2000 survey, EUROSTAT, European Communities, Luxemburg 2003, tab. 1, s. 67, Agricultural statistics. Main results - 2007-08, EUROSTAT, European Communities, Luxemburg 2009, tab. 1.2.2, s. 25 .

\section{Struktura agrarna w krajach przyjętych do Unii Europejskiej po 2004 r.}

Podobnie jak w przypadku państw tzw. starej piętnastki, tak też na poziomie krajów - nowych członków Unii Europejskiej w strukturze agrarnej można zauważyć duże zróżnicowanie. Przyglądając się kwestiom ilości gospodarstw rolnych w poszczególnych państwach, należy bez wątpienia uwzględnić wielkość poszczególnych krajów, stan potencjalnych gruntów wykorzystywanych do celów rolniczych, strukturę i rodzaj 
upraw, a nade wszystko ogólne warunki przyrodnicze. Niemniej o poziomie, dynamice i kierunku zmian struktury obszarowej tych państw można pewne wnioski wyciagać zestawiając dane z okresu tuż przedakcesyjnego oraz pierwszych lat członkostwa.

Liczba gospodarstw w nowych krajach Unii Europejskiej w latach 2003-2007

\begin{tabular}{|c|c|c|c|}
\hline \multirow{3}{*}{ Kraj } & \multicolumn{3}{|c|}{ Lata } \\
\hline & 2003 & 2005 & 2007 \\
\hline & \multicolumn{3}{|c|}{ tys. } \\
\hline Bułgaria & 665,6 & 534,6 & 493,1 \\
\hline Cypr & 45,2 & 45,2 & 40,1 \\
\hline Czechy & 45,8 & 42,3 & 39,4 \\
\hline Estonia & 36,9 & 27,8 & 23,3 \\
\hline Litwa & 272,1 & 253,0 & 230,3 \\
\hline Łotwa & 126,6 & 128,7 & 107,8 \\
\hline Malta & 11,0 & 11,1 & 11,0 \\
\hline Polska & 2172,2 & 2476,5 & 2391,0 \\
\hline Rumunia & 4484,9 & 4256,2 & 3931,4 \\
\hline Słowacja & 71,7 & 68,5 & 69,0 \\
\hline Słowenia & 77,2 & 77,2 & 75,3 \\
\hline Węgry & 773,4 & 714,8 & 626,3 \\
\hline
\end{tabular}

Źródło: EUROSTAT, Number of agricultural holdings - [tag00001], data sporządzenia: 1.07.2010.

Spośród nowych państw członkowskich najwięcej gospodarstw znajduje się w Rumunii. Mimo, iż w latach 2003-2007 odnotowano spadek ich liczby o 12,3\%, to jednak nadal jest ich prawie $4 \mathrm{mln}$. Na drugim miejscu plasuje się Polska - jedyny kraj, w którym liczba jednostek produkcyjnych rolnictwa w rozpatrywanym okresie wzrosła o 9,2\%. Najwięcej gospodarstw ubyło w Estonii, ich liczba zmniejszyła się aż o 36,9\%. Duży spadek, bo o 25,9\% odnotowano także w Bułgarii. Na Malcie zaś liczba rolniczych jednostek produkcyjnych nie uległa zmianie.

Zmiany liczby gospodarstw w krajach Unii w latach 2003-2007

\begin{tabular}{|c|c|c|c|c|c|c|c|c|c|c|}
\hline & & \multicolumn{8}{|c|}{ Grupy obszarowe } & \multirow{3}{*}{$\begin{array}{c}\text { Średni } \\
\text { obszar }^{\text {a }} \\
\text { w ha }\end{array}$} \\
\hline \multicolumn{2}{|c|}{ Kraj } & \multicolumn{2}{|c|}{ do 5 ha } & \multicolumn{2}{|c|}{ 5-20 ha } & \multicolumn{2}{|c|}{$20-50$ ha } & \multicolumn{2}{|c|}{50 ha i więcej } & \\
\hline & & tys. & $\%$ & tys. & $\%$ & tys. & $\%$ & tys. & $\%$ & \\
\hline 1 & 2 & 3 & 4 & 5 & 6 & 7 & 8 & 9 & 10 & 11 \\
\hline \multirow[t]{2}{*}{ Bułgaria } & A & 644,3 & 96,8 & 13,7 & 2,1 & 2,5 & 0,4 & 5,1 & 0,8 & - \\
\hline & B & 467,8 & 94,9 & 15,5 & 3,1 & 3,6 & 0,7 & 6,2 & 1,3 & 24,3 \\
\hline \multirow[t]{2}{*}{ Cypr } & A & 39,6 & 87,6 & 4,4 & 9,7 & 0,9 & 2,0 & 0,4 & 0,9 & - \\
\hline & B & 34,7 & 86,5 & 4,7 & 11,7 & 0,8 & 2,0 & 0,4 & 1,0 & 4,9 \\
\hline \multirow[t]{2}{*}{ Czechy } & A & 26,6 & 58,1 & 9,1 & 19,9 & 3,9 & 8,5 & 6,2 & 13,5 & - \\
\hline & B & 19,8 & 50,3 & 8,5 & 21,6 & 4,5 & 11,4 & 6,6 & 16,8 & 134,6 \\
\hline
\end{tabular}




\begin{tabular}{|c|c|c|c|c|c|c|c|c|c|c|}
\hline 1 & 2 & 3 & 4 & 5 & 6 & 7 & 8 & 9 & 10 & 11 \\
\hline \multirow[t]{2}{*}{ Estonia } & A & 18,7 & 50,7 & 12,6 & 34,1 & 3,4 & 9,2 & 2,1 & 5,7 & - \\
\hline & B & 8,4 & 36,1 & 9,3 & 40,0 & 3,0 & 12,9 & 2,6 & 11,2 & 66,5 \\
\hline \multirow[t]{2}{*}{ Litwa } & A & 168,9 & 62,1 & 85,7 & 31,5 & 12,5 & 4,6 & 5,1 & 1,9 & - \\
\hline & B & 139,3 & 60,5 & 71,1 & 30,9 & 13,0 & 5,6 & 6,9 & 3,0 & 25,0 \\
\hline \multirow[t]{2}{*}{ Łotwa } & A & 64,1 & 50,6 & 49,5 & 39,1 & 9,3 & 7,3 & 3,8 & 3,0 & - \\
\hline & B & 44,1 & 40,9 & 47,8 & 44,3 & 10,8 & 10,0 & 5,1 & 4,7 & 32,2 \\
\hline \multirow[t]{2}{*}{ Malta } & A & 10,7 & 97,3 & 0,2 & 1,8 & 0,0 & 0,0 & 0,0 & 0,0 & - \\
\hline & B & 10,7 & 97,3 & 0,3 & 2,7 & 0,0 & 0,0 & 0,0 & 0,0 & 1,2 \\
\hline \multirow[t]{2}{*}{ Polska } & A & 1444,8 & 66,5 & 619,2 & 28,5 & 90,3 & 4,2 & 17,9 & 0,8 & - \\
\hline & B & 1637,3 & 68,5 & 628,7 & 26,3 & 101,4 & 4,2 & 23,6 & 1,0 & 12,3 \\
\hline \multirow[t]{2}{*}{ Rumunia } & A & 4205,1 & 93,8 & 256,3 & 5,7 & 9,5 & 0,2 & 14,1 & 0,3 & - \\
\hline & B & 3530,7 & 89,8 & 370,1 & 9,4 & 16,1 & 0,4 & 14,4 & 0,4 & 11,0 \\
\hline \multirow[t]{2}{*}{ Słowacja } & A & 65,9 & 91,9 & 2,5 & 3,5 & 0,9 & 1,3 & 2,4 & 3,3 & - \\
\hline & B & 60,2 & 87,2 & 4,6 & 0,7 & 1,4 & 2,0 & 2,9 & 4,2 & 119,2 \\
\hline \multirow[t]{2}{*}{ Słowenia } & A & 44,4 & 57,5 & 30,3 & 39,2 & 2,2 & 2,8 & 0,2 & 0,3 & - \\
\hline & B & 44,5 & 59,1 & 27,7 & 36,8 & 2,8 & 3,7 & 0,4 & 0,5 & 7,5 \\
\hline \multirow[t]{2}{*}{ Węgry } & A & 693,3 & 89,6 & 55,2 & 7,1 & 14,2 & 1,8 & 10,7 & 1,4 & - \\
\hline & $\mathrm{B}$ & 560,2 & 89,4 & 416 & 6,6 & 12,4 & 2,0 & 12,1 & 1,9 & 28,8 \\
\hline
\end{tabular}

- brak danych;

A - dotyczy 2003;

B - dotyczy 2007;

a obejmuje użytki rolne, trwałe pastwiska, trwałe uprawy oraz ogródki przydomowe.

Źródło: Obliczenia własne na podstawie EUROSTAT, Agricultural holdings with agricultural area $<5$ ha - [tag00002], data sporządzenia: 1.07.2010, EUROSTAT, Agricultural holdings with agricultural area 5-<20 ha - [tag00003], data sporządzenia: 1.07.2010, EUROSTAT, Agricultural holdings with agricultural area 20-<50 ha - [tag00004], data sporządzenia: 1.07.2010, EUROSTAT, Agricultural holdings with agricultural area $>=50$ ha - [tag00005], data sporządzenia: 1.07.2010, Agricultural statistics. Main results - 2007-08, EUROSTAT, European Communities, Luxemburg 2009, Tab. 1.2.2, s. 25.

Mimo, iż w najmniejszej grupie obszarowej w latach 2003-2007 ogólnie zaobserwować można tendencje spadkowe, to jednak w strukturze agrarnej nowych państw członkowskich przeważają gospodarstwa niewielkie do 5 ha. Najwięcej w tym przedziale ubyło gospodarstw w Estonii (14,6\%). Niewielki wzrost natomiast zanotowano w Polsce (o 2\%) i na Słowenii (o 1,6\%). Procentowy udział pozostałych grup obszarowych generalnie wzrósł. Jedynie w kilku krajach, tj. w Polsce, na Słowacji, Słowenii i Węgrzech nastąpił w przedziale 5-20 ha niewielki spadek rzędu 0,5-2,8\%. Najwyższą średnią powierzchnią gospodarstwa charakteryzują się Czechy i Słowacja. Polska na tle tych państw wypada słabo, tym bardziej, że wedle krajowych danych GUS w 2007 r. średnia powierzchnia gruntów w gospodarstwie wynosiła 7,24 ha, z czego 6,27 ha zajmowały użytki rolne. Różnice w liczbach wynikają, jak już zaznaczono, $\mathrm{z}$ odmiennych definicji obszaru gruntów zaliczanych do gospodarstwa.

W państwach EU-15 ogólnie spadkowi uległa liczba jednostek produkcyjnych, a tym samym zwiększył się średni obszar gospodarstwa rolnego. Za pozytywny należy 
także uznać generalny spadek ilości gospodarstw najmniejszych do 5 ha. Można zauważyć, że na tle tych krajów szczególnie niekorzystnie wypada struktura agrarna Rumunii, Polski z ogromną ilością jednostek produkcyjnych, a także Węgier i Bułgarii. W świetle powyższej analizy należy zauważyć, że w krajach zachodnioeuropejskich dynamiczne zmiany na poziomie struktury agrarnej obserwuje się już od lat 60 . Ich przesłankę stanowią przede wszystkim czynniki ekonomiczne. Istotnymi zaś bez wątpienia stymulatorami są działania realizowane na poziomie polityki poszczególnych państw, a także mechanizmy wprowadzane w ramach Wspólnej Polityki Rolnej Unii Europejskiej. 
